IRA-International Journal of Education \& Multidisciplinary Studies

ISSN 2455-2526; Vol.12, Issue 02 (August, 2018)

Pg. no. 40-47.

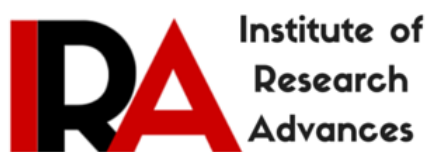

Institute of Research Advances

http://research-advances.org/index.php/IJEMS

\title{
The Impasse of Good Governance and Accountability in Democratic Governance in Nigeria: 1999 - 2015
}

\author{
Haruna Ayuba Ph.D. \\ University of Maiduguri, Department of Political Science, P.M.B. 1069, Maiduguri, Borno State, \\ NIGERIA.
}

Type of Review: Peer Reviewed.

DOl: http://dx.doi.org/10.21013/jems.v12.n2.p2

\section{How to cite this paper:}

Ayuba, H. (2018). The Impasse of Good Governance and Accountability in Democratic Governance in Nigeria: 1999 - 2015. IRA International Journal of Education and Multidisciplinary Studies (ISSN 2455-2526), 12(2), 40-47.doi: http://dx.doi.org/10.21013/jems.v12.n2.p2

(C) Institute of Research Advances.

\section{(c)) EY-NC}

This work is licensed under a Creative Commons Attribution-Non Commercial 4.0 International License subject to proper citation to the publication source of the work.

Disclaimer: The scholarly papers as reviewed and published by the Institute of Research Advances (IRA) are the views and opinions of their respective authors and are not the views or opinions of the IRA. The IRA disclaims of any harm or loss caused due to the published content to any party.

Institute of Research Advances is an institutional publisher member of Publishers Inter Linking Association Inc. (PILA-CrossRef), USA. The institute is an institutional signatory to the Budapest Open Access Initiative. Hungary advocating the open access of scientific and scholarly knowledge. The Institute is a registered content provider under Open Access Initiative Protocol for Metadata Harvesting (OAI-PMH).

The journal is indexed \& included in WorldCat Discovery Service (USA), CrossRef Metadata Search (USA), WorldCat (USA), OCLC (USA), Open J-Gate (India), EZB (Germany) Scilit (Switzerland), Airiti (China), Bielefeld Academic Search Engine (BASE) of Bielefeld University, Germany, PKP Index of Simon Fraser University, Canada. 


\begin{abstract}
The administration of democratic governance since 1999 throughout the fourth republic has had chequred history of low productivity arising from inability to provide the much needed goods and services by governments to its citizens at different strata'sthroughout the federation. These have impacted on the provision of goods and services. The study revealed that the fourth republic has battled with governance hindered by weak institutions responsible for provision of goods and services. Thus the study revealed within the integration theorists that unity and effective and efficient institutions to administer effectively is sacrosanct and inevitable for sustenance of good governance. To arrive at this conclusion the study reviewed different literature on the above subject matter and recommend reorganization and effective implantations of rules and procedures for sustenance of good governance and accountability is necessary. The study relied on qualitative sourced data for analysis.
\end{abstract}

Kew words: Good Governance, Development, fourth republic, integration, accountability

\title{
1. Introduction
}

Democratic politics and good governance in Nigeria did not fare better in the Second Republic as well as the Third Republic. But since 29 May, 1999, when the Fourth Republic was ushered in, politicians in government have continued to use the phrase "dividends of democracy" which refer to the provisions of material welfare to the people, such as roads, rural electrification, potable water, improved educational and health facilities, housing, amongst others, (Odo,2015). However, it is pertinent to note that democracy and good governance in Nigeria and elsewhere in the world cannot be achieved through the mere provisions of material welfare such as roads, jobs, food, electricity, education, health care services and others since they are even easier to provide under authoritarian rule. This was observed by Elaigwu (2011) cfOdo, (2015) as a stumbling block to development. One of the factor that jettisoned the sustenance of good governance in Nigeria has been weak integration and patriotism by elites and policy makers at different strata's.

The world over, military dictatorship is known as a government ruled by decrees and sustained by gun power which the actors in government does not recognized the constitutional role of the people they governed (Olorunsola, 1977; Oko, 1997). As such, the military in the case of Nigeria suspended the Nigerian constitution during the military era before the return of power from the military to the civilian rule in 1999 (Ikpe, 2000;Terwase, Yerima, Abdul-Talib, \& Ibrahim, 2016). More so, the Nigerian government during the civilian rule established constitutional laws to govern the affairs of the country with effective use of the 1999 Constitution (Wehner, 2002). It then calls for credible governance and accountability since the return of democratic governance in Nigeria which needs to showcase the good governance credentials and to be accountable to the people they represent in power. Under the military era, the military may choose not to give account to the people and nothing happens to those in authority (Lewis, 1994; Lewis, 1996). Those who choose to protest against the military government may face jail term whereas democratic governance requires accountability to the people. This research paper therefore, focuses on the impasse of good governance and accountability in democratic governance in Nigeria from 1999 to 2015. These were the years President Obasanjo, President Yar'Adua and President Jonathan ruled the affairs of Nigeria. The work of Terwase, Abdul-Talib, \& Zengeni (2015) opined that, some of the challenges of good governance from the economic perspective are unemployment, poverty, transparency and accountability. Until such issues are addressed adequately, if not, the quest for good governance in Nigeria's democratic nation is going to suffer setback in relation to both political and socio-economic governance (Akwara, Akwara, Enwuchola, Adekunle, \&Udaw, 2013).

\section{Integration Theory}

The word integration connotes bringing together all entities, units, and affiliations. Integration can be practiced in a small organization, group of people, community, locality, state, nation or country as the case may be. In relation to this work, integration theory is viewed from the perspective of an entity called Nigeria which is a federal state within Africa.Integration research is not without theoretical antecedents. The conceptual foundations of the theory can be traced back to the classics (Adam Smith and David Ricardo). According to Domonkos, (2011) the cconcrete theoretical and methodological interpretations of techniques of analyses employed are based mainly on neoclassical and welfare international economics, which examined the benefits gained from international trade. In the political science field of neo-functionalism, federalism and the analyses relating to inter-governmentalism are recognized as the main theoretical currents with regard to attempts at integration. 
The subject of integration involves legal, sociological, historical and cultural research. In connection with integration, as a new field of scholarship, is increasingly characterized by a multidisciplinary approach (combining history, economics, law, sociology, political science and culture). We can define integration as a state or as a process, as a fact or as an aim to be achieved. In general, integration theories according to Domonkos, (2011) focus on five important dimensions of the process of integration as follows. (a). the content (or essence) of integration processes; (b). the organizational forms and institutions of integration; (c). regulation (policies) and governance of integration; (d). the advantages and disadvantages of integration (cost-benefit analysis); and finally (e). the problems of integration maturity (capacities or capabilities for integration). The country has about 36 States, and the Federal Capital Territory, Abuja as the capital. All these states cut across the North and South of the country where they are divided into six geo-political zones (Terwase, Abdul-talib, Wahid, Puldu, Siben, Adesina, \& Godwin, 2017). All these states irrespective of the zones should be integrated into the whole as one country where there is inclusiveness in relation to good governance at all levels. The country is sub-divided into three levels namely, the Federal Government, State Government and Local Government.

Some of the factors that affect good governance and accountability in Nigeria are ethnicity and religious affiliations. The leaders in power tend to focus more on their ethnic and religious affiliation rather than focusing on the development of the country at large. Such character neglects inclusiveness and bridging the gap that exist in relation to poverty and unemployment, thereby creating more wholes against political and socio-economic development (Akwara, Akwara, Enwuchola, Adekunle, \&Udaw, 2013).

Furthermore, Arowolo\&Aluko (2012) explained that, political participation and good governance promotes the tenants of democratic governance. Therefore, all the government agencies should participate positively in carrying out their duties on behalf of the government and there should be inclusiveness among the people, while provision of basic amenities, infrastructural development should cut across all states in Nigeria. That will proof all parts of the country been integrated into the whole. However, where there is economic development only in few states that belongs to the powers that be, such may create room for corruption and unaccountable resources.

Onwubu (1975) express that there are no Nigerians in relation to 'English' in the United Kingdom and 'French' in France, rather, Igbo, Hausa, Fulani, Yoruba, Tiv, Idoma, Kanuri in Nigeria. Therefore, there is need for political and economic integration in Nigeria where all would "be a part of", inclusive and integrated into a whole. As long as other sections of the country are neglected be it politically or economically, there would be underdevelopment of the said section. Good governance should cut across all sections and levels of Nigeria.

\section{Governance}

The term governance has preoccupied the minds of policymakers, administrators, non-governmental organizations and the academic circle in the recent years. The exercise of power and authority in both the political and economic spheres in the words of Kwanashie (2000) is the exercise of political power for the direction and management of society-links decision making process of carrying out specific responsibilities of government. The executive, legislative and judiciary have certain responsibilities to perform. Therefore governance is the totality of the process of constituting a government as well as of administering a political community. Although government according to Ikpe (2000) exists in both the private and public sectors governance on the other hand is the total ability to organize, synthesize and direct the various actions of the working part of government machinery in order for such a government to perform meaningfully, credibly, and acceptably. The deepest cause of development failure is not a lack of resources or international isolation. Rather it is a lack of good governance- the inability or unwillingness to apply public resources effectively to generate public good, (Larry Diamond, 2004; Adeleke\&Marcellinus 2017).

Thus, governance involves both the governing class and the governed people; and good governance on the other hand must of necessity be democratic, entail popular participation by the people, accountability and ensures freedom among other things.

According to Yaqub and Mikailu, (2003) it is the umbilical cord that links the governor and the governed. Thus governance can be regarded as an act, manner, office, or power of governing government, state of being governed or method of government or regulations. Similarly, Goran Hyden in Weiss (2000:795) refers to it as mainly running government and other public agencies or private ones with social purposes. In the same manner The Commission on Global Governance defines governance as the sum of the many ways individual and institutions, 
public and private, manage their common affairs. It is the continuing process through which conflicting or diverse interest may be accommodated and cooperative action may be taken.

The concept of governance is seen as a set of values, policies and institutions through which the society manages economic, political as well as social processes at different levels, on the basis of interaction among the government, civil society and private sector. In more precise manner, governance is one which is concerned with authority, exercise of power, exerting influence and management of the countries' social as well as economic resources leading to development. It is the conscious management of regime structure with a view to enhancing the legitimacy of the public realm, (Hyden,1992:7; Sahni,2003:2) Similar observation was made by one most closely associated with the term, James Rosenau. According to him whether at the grassroots or global levels, it also includes the many other channels through which commands flow in the form of goal framed, directives, issues and policies pursued. Therefore Governance is an exercise of power through country's economic, social, and political institutions in which institutions represent the organizational rules and routines, formal laws, and informal norms and procedures that together shape the incentives of public policy-makers, overseers, and providers of overall public services, (UNDP, 1997)

\section{Good Governance}

The notion of good governance as it dominates the pattern and the best way of administration in the recent years is nothing but people oriented government. The World Bank (1994) defines good governance as "the manner in which power is exercised in the management of a country's economic and social resources for development" It is essentially the combination of transparent and accountable institutions, strong skills and competence, and a fundamental willingness to do the right thing. Those things are fundamental that enable a government to deliver services to its people efficiently.

Gisselquist (2012) also noted that proponents of the good governance agenda particularly Multilateral Agencies see it as a worthy goal as a means through which to impact a variety of other outcomes, particularly economic growth and development. In poorly governed countries, it is argued, corrupt bureaucrats and politicians badly hinder development efforts by abusing government funds and aid contributions or misdirecting them into unproductive activities. This is peculiar to governments that are not accountable to their citizens and with inefficient bureaucracies and weak institutions are unwilling or unable to formulate and implement pro-growth and pro-poor policies.

In other words good governance refers to polity which defines governance as act of governing a state or a people. According to Eric, (2003:63) good governance stands for acceptable government and desirable leadership. The two terms are not negotiable: there must be government; the said government must necessarily be acceptable by the populace.

One may ask why good governance is important and integral in the administration of a given country. According to Bliss, S. (2010), good governance helps a country to gain maximum utility from its resources in a manner which is economically, environmentally and socially sustainable. It ensures that political and economic activities benefit the whole of society rather than a few individuals or selected groups.

The major benefits delivered by good governance include the followings, (World Bank ,1994)

a) A stable political and economic environment which will encourage investment and a flourishing business sector, and

b) the sustainable development of a country's resources,

c) Improvement and development of infrastructure related to basic living standards, for example, sanitation, housing, running water,

d) The development of health and education facilities which are accessible to all,

e) The protection of human rights - it is only through good governance that a society can guarantee to meet the basic needs of its citizens such as the right to food, security, the right to an education, the right to shelter, the right to health care and the right to a fair, equitable and accessible justice system,

f) Protection and improvement of the environment, for example, lower rates of air, water and ground pollution; conservation of forests. 
In light of these the findings of World Bank Report, (1977) emphasized that the state is capable, and indeed should perform the role of producing welfare-enhancing outcomes. Therefore, Weiss, (2000:805; Jega, (2002) concluded that human governance involves those structures and processes that support the creation of participatory, responsive and accountable polity (that is good political governance) embedded in a competitive, nondiscriminatory, yet equitable economy (that is good economic governance ). This way, people must be given the ability to be self-organized (That is good civic governance). Babawale, (2007:8) clarify this by defining good governance as the exercise of political power to promote the public good and the welfare of the people. The public good incorporates the norms or values of a free, just ordered and law-governed society as well as those of happiness and the good life. He added that following are inalienable attributes of good governance are as follows; Accountability, , Transparency in governmental procedures, Expectation of rational decisions, Predictability in government behavior, Openness in government transactions, Free flow of information, Respect for the rule of law and protection of civil liberties, Freedom of the press and, Decentralization of power structure and decision-making.

Thus a government that is responsive and provides for the needs and welfare of its citizenry is a good government. Broadly speaking, the term governance according to Sharma, S.D. (2007) encompasses all aspects of the way a country is governed. Good governance has several characteristics. It is participatory, consensus oriented, accountable, transparent, responsive, effective, efficient, equitable, and inclusive and follows the rule of law. At a minimum, good governance requires fair legal frameworks that are enforced impartially by an independent judiciary and its decisions and enforcement are transparent or carried out in a manner that follows established rules and regulations. He asserts that since accountability cannot be enforced without transparency and the rule of law, accountability is a key requirement of good governance. Not only governmental institutions, but also private sector and civil society organizations must be accountable to the public and to their institutional stakeholders.Moreover, given that a society's well-being depends on ensuring that all its members feel that they have a stake in it, good governance requires that institutions serve all stakeholders fairly. That is, what needs to be measured is the government's delivery of public goods and not just its budgetary provisions, its actual accomplishments, and its good intentions.

Institutions that yield good governance are composed of both formal which includes constitutions, laws, and regulations and the informal such as social norms, customs, and traditions, rules that constrain human economic behavior. Specifically, institutions set the framework of rules and incentives that affect how people, organizations, and firms utilize resources in political and economic decision making, or how they "play the game." According to North, cited in Sharma, S.D. (2007) when incentives encourage individuals to be productive, economic activity and growth takes place. However, when they encourage unproductive or predatory behavior, economies stagnate. Informal interpersonal exchanges and social networks succeed and serve the needs of traditional societies and modern economies given their relations to institutions of government where connections and favoritism and cronyism thrive. In providing specific rules of the game, political and economic institutions create the conditions that enable the functioning of a modern economy such as formal institutions, by securing property rights, establishing impartial polity and judicial system, and implementing flexible laws that allow a range of organizational structures, create an economic environment that induces increasing productivity. To North, institutions are "growth enhancing" because they reduce uncertainty and transaction costs. Thus, North's paradigm is often labeled as the "new institutionalism" because it has at its core a set of ideas derived from the analysis of "transaction costs"-that is, costs that result from the imperfect character of real-world institutions and that have to be surmounted in order for economic and political activity to occur which translate to good governance.

Today, liberal democracy justifiably enjoys near-universal appeal and is regarded as the ideal system of government. Accordingly, liberal democracy is a form of government by means of which citizens, through open and free institutional arrangements, are empowered to choose and remove leaders in a competitive struggle for the people's vote.According to Robert Dahl, a truly representative democratic government must be based on the principles of popular sovereignty; competitive political participation and representation; an independent judiciary; free, fair and regular elections; universal suffrage; freedom of expression and conscience; the universal right to form political associations and participate in the political community; inclusive citizenship; and adherence to the constitution and the rule of law.

\section{Consolidation of Good Governance in Nigeria}

Since the 1990s the term good governance has enjoyed growing popularity amongst academics and policy making circle across the globe. However, at the core of good governance agenda lies a concern about the rules and practices 
according to which government are chosen and state power and authority are exercised. Donor programmes under the three heading of 'good governance' comprise a range of activities that can be listed under three broad categories, (World Bank 2006 cf Fritz, \&Menocal, 2006). These are: (i) State/bureaucratic capability-This includes issues related to financial management and public administration, among others. (ii) Accountability and oversight institutions to provide checks and balances. This includes issues related to voice and accountability, transparency, the role of the media and civil society, the rule of law, executive constraints and democratic representation and participation among others. (iii) Overall Performance: This includes control of corruption, service delivery and policy outcomes among others.

The efforts that build these pillars in Nigeria according to Jega, (2007) are daily confronted by and challenged by substantial threats, which manifest themselves for example in the reckless misrule by elected officials, corrupt practices by public officials, insensitivity to and intolerance of opposing views and perspective, patronage, weak or absent political ideologue, communal and ethno-religious conflicts and general insecurity of lives and property. He asserts that there is a strong relationship between good governance and democratic consolidation with reservation as some countries in Asia such as Singapore, China, Indonesia, and Malaysia among others had attained relative stage of development under autocratic or authoritarian regimes. Thus, the more public and elected officials in the theatre of patron-client party politics exhibits irresponsibility, seem unaccountable and irresponsive to popular needs and aspirations, and the more poorly they conduct themselves in governance and state craft the greater the threat to democratic consolidation and sustainability.

Good governance to Diamond, (2005a) consists of several dimensions. One is the capacity of the state to function in the service of the public good, effective functioning requires knowledge of the policies and rules that best serve the public good, and hence training of state officials in their various professional civil services with a set of norms and rewarding those who performs well in their roles.

The second dimension of good governance is commitment to the public good. It may be generated by dedicated and charismatic leadership. It may drive from a cultural ethnic that appreciate and a structure of institutional incentives that rewards disciplined service to the nation or the general community.

The third dimension of good governance is transparency, the openness of state business and conduct to the security of other state actors and the public. Transparency requires freedom of information including an act to ensure that citizens can acquire information about how government makes decisions, conduct business and spends public money. This dimension makes it difficult, to fit in the state of Nigeria as a result of its bad transparency record. Diamond, (2005b) observed that trends and public opinion in Nigeria show how trust in democratic institutions moves in tandem with support for democracy between the year 2001-2005 in Nigeria declining trust in part of a broader disillusionment. Satisfaction with the working of democracy plunged from 81 percent in 2000 to 25 percent in 2005, support for democracy declined (from 84 to 65 percent) and trust in the president plummeted from 78 to 26 percent. In this same period, approval of the performance of the national assembly plunged from 58 to 23 percent and trust in the institution declined from 66 to 55 percent. The reasons for these various declines were growing citizen disappointment with corruption, electoral fraud, and abuse of power.

The fourth dimension is accountability. Governing agents are more likely to be responsible and 'good' when they are answerable for their conduct to the society in general and to other specific institutions that monitor their behavior and can impose sanctions upon them. Cronies in Nigerian politics and some governing agents are not accountable to anyone except their patrons or godfathers who install them there. Hence the public are left at the mercy of unpredictable events and circumstances.

The fifth dimension of good governance is the rule of law. Governance can be good when it is restrained by the law: when the constitution and laws are widely known, when the law is applied equally to the mighty and the meek, when everyone has reasonable access to justice, and when there are capable, independent authorities to adjudicate and enforce the law in a neutral, predictable, and efficient fashion. This has proved difficult in Nigeria.

Therefore, democracy and good governance to Diamond, (2005a) promotes economic and political development. Real democracy that is competitive, open, participatory and responsive provides a means for citizens to monitor and evaluate the performance of good government and to remove officials and representatives who do not serve the public interest. When government itself is transparent and disciplined in its commitment to the public good 
it provides credible signals to the rest of the society about what type of behaviour can be expected. In light of these the Nigerian state shouldn't have least expected the devastating effect of Boko Haram that strucke in some parts of Nigeria.

By contrast, bad governance and most specifically rampant corruption, lack of adherence to policies and programs constitute one of the major banes of development in Nigeria. Extensive corruption and cronyism as it abounds in Nigeria's politics discourages private investment, distorts resource allocation, deforms policies, swells budget deficits, diverts resources and squanders large amount of resources. Funds that could go to educate and inculcate children, pave roads, build markets, dig wells, generate electricity instead wind up in overseas bank accounts and real estates, or financing the importation of expensive cars and other luxury goods for the already wealthy individuals. In badly governed societies such as Nigeria, individuals seek governmental positions in order to collect rents and accumulate personal wealth to convert public resources into private goods. In such instances, there is no commitment to the public good and no confidence in the possible means. Communities as well seek government jobs and favours, in a zero-sum struggle over a stagnant and potentially fleeting stock of resources. Thus there is no respect for the law, and no rule of law.

\section{Conclusion}

In conclusion, there are issues that affect our democratic governance in Nigeria within the period under study which are: The judicial system appears compromised. The police enforce the law selectively. Customs officials do not inspect the goods. Manufacturers do not produce, bankers do not invest, borrowers do not repay, and contracts do not get enforced. Government decisions and transactions are deliberately opaque in order to hide their corrupt nature and evade embarrassing disclosure. Lacking a sense of public purpose, discipline, and esprit de corps, the civil service, police, customs, and other public institutions function poorly, Agbaje, et al (2004:225). At the level of political parties, a political party must remain above the activities of its members in government while retaining its right to monitor and discipline members whose activities in government are at variance with the values, policies and aspirations of the party. Reflecting on the Nigerian experience, scholars lamented that more often than not, political parties in Nigeria only serve as machinery for winning votes during elections after which they are abandoned. Within this context, also the elected government often tends to abandon the ideology of its own party Soleye, O et al (2000:7). Though there are other external factors responsible for the above, our concern in this study is internal source as pointed out in this section.

\section{References}

[1]. Adeleke, Adegbami\&Marcellinus, Adepoju, Banji (2017) Good Governance in Nigeria: a Catalyst to National Peace, Stability and Development, African Research Review, An International Multi - Disciplinary Journal, Bahir Dar, Ethiopia Afrrev Vol. 11 (4), Serial No. 48, September, 2017:144 -155 ISSN 1994 - 9057 (Print) ISSN 2070 -0083 (online).

[2]. Agbaje. A.A.B; Diamond, L; Onwudiwe, E. (2004) Nigeria's Struggle for Democracy and Good Governance: A Festschrift for OyeleyeOyediran, Ibadan, Ibadan University Press

[3]. Akwara, A. F., Akwara, N. F., Enwuchola, J., Adekunle, M., \&Udaw, J. E. (2013). Unemployment and poverty: Implications for national security and good governance in Nigeria. International Journal of Public Administration and Management Research, 2(1), 1-11.

[4]. Arowolo, D. E., \&Aluko, O. A. (2012). Democracy, political participation and good governance in Nigeria. International Journal of Development and Sustainability, 1(3), 797-809.

[5]. Babawale, T. (2007) Good Governance, Democracy and Democratic "Best Practices": prescription for Nigeria, Lagos, Centre for Black and African Arts and Civilisation, (CBAAC)

[6]. Bliss, S. (2010) “ 'Good' Governance - Secondary HSIE; Art of Governance - available from Professional Teachers' Council accessed at http://www.abc.net.au/civics/rights/teach.htm and http://www.abc.net.au/civics/oneworld/nswteach.htm on 20/19/2011

[7]. Diamond, L. (2005a) Democracy, Development and Good Governance: The inseperatable links; Being a paper presented at the Annual Democracy and governance Lecture, Center for Democratic Development, at the British Council Hall, Accra, Ghana, March 2005.

[8]. Diamond, L.(2005b) "Promoting Democracy in Post-Conflict and failed states: and challenges", Being a paper prepared for the National Policy Forum on Terrorism, Security, and America's purpose, September 6-7, Washington $\mathrm{DC}$

[9]. Domonkos, Endre (2011) Integration theories and integration forms, EU-Integration knowledgesaccessed on www.külker.hu/wp-content/uploads/...Integration-theories-and-integration-forms.ppt

[10]. Eric, O. C. (2003) "Accountability and Good Governance" in Kwanashie, M. (Ed) Politics and Power Relations in Nigeria, Lagos, Dat and Partners Logistics Ltd

[11]. Fritz, V.A. \&Menocal, R. (2006) Building Developmental states: From theory to practice, Working Paper 274, September 2006, London, Overseas Development Institute 
[12]. Gisselquist, Rachel M. (2012) Good Governance as a Concept, and Why This Matters for Governance for Sustainable Human Development, UNDP Policy Paper (UNDP 1997)Development Policy, Working Paper No. 2012/30, March 2012, ISBN 978-92-9230-493-5

[13]. Hyden, G. (1992) "Governance and the study of Politics" in Hyden, G. \& Michael, B. Governance and Politics in Africa, (Ed), London, Lynne Rienner Publisher

[14]. Ikpe, U. B. (2000). Patrimonialism and military regimes in Nigeria. African Journal of Political Science/Revue Africaine de Science Politique, 146-162

[15]. Jega, A.M. (2007) Democracy, Good Governance and Development in Nigeria, Ibadan, Spectrum Books

[16]. Kwanashie, M. (2000) "Governance and Political Stability for Economic Development: Lessons of Experience", Central Bank of Nigeria: Economic and Financial Review,

[17]. Lewis, P. (1996). From prebendalism to predation: the political economy of decline in Nigeria. The Journal of Modern African Studies, 34(1), 79-103.

[18]. Lewis, P. M. (1994). Endgame in Nigeria? The politics of a failed democratic transition. African Affairs, 93(372), 323340.

[19]. Odo, Linus Ugwu (2015) Democracy and Good Governance in Nigeria: Challenges and Prospects Global Journal of Human Social Science For Political Science, Volume 15 Issue 3 Version 1.0 Year 2015, Online ISSN: 2249-460x \& Print ISSN: 0975-587X

[20]. Oko, O. (1997). Lawyers in Chains: Restrictions on Human Rights Advocacy Under Nigeria's Military Regimes. Harv. Hum. Rts. J., 10, 257.

[21]. Olorunsola, V. A. (1977). Soldiers and Power: the development performance of the Nigerian military regime (No. 168). Hoover Inst Pr.

[22]. Onwubu, C. (1975). Ethnic identity, political integration, and national development: the Igbo diaspora in Nigeria. The Journal of Modern African Studies, 13(3), 399-413.Vol.38.No4

[23]. Sahni, P. \&Medury, U. (2003) Governance for Development: Issues and Strategies, Delhi, Prentice-Hall of India Private Limited

[24]. Sharma, Shalendra D. (2007)Democracy, Good Governance, and Economic Development, Taiwan Journal of Democracy, Volume 3, No.1: 29-62

[25]. Soleye, O; Abdullahi, B; Abati, R. (2000) 'Political Parties and Good Governance in Nigeria' Africa Leadership Forum: 34th Farm House Dialogue, Dialogue 34, 7-9 April 2000

[26]. Terwase, I. T., Yerima, H. M., Abdul-Talib, A. N., \& Ibrahim, M. B. (2016). The Issues behind Agitations, Conflict and War: A Case of Nigeria. International Review of Management and Marketing, 6(7S), 17-21.

[27]. Terwase, I. T., Abdul-Talib, A. N., \& Zengeni, K. T. (2015). The Role of ECOWAS on Economic Governance, Peace and Security Perspectives in West Africa. Mediterranean Journal of Social Sciences, 6(3), 257

[28]. Terwase, I. T., Abdul-Talib, A. N., Wahid, R.,Puldu, G. S.,Siben, E., Adesina, O.\& Godwin, D. (2017). Conflict Resolution: Applying the Zoning Formula Model to Resolve Biafra Agitation. Journal of Asian Review of Public Affairs and Policy, 2(1)

[29]. Wehner, J. (2002). Parliament and the power of the purse: the Nigerian constitution of 1999 in comparative perspective. Journal of African Law, 46(2), 216-231.

[30]. World Bank, (1994) 'Good Governance- Concept, Meaning and Features: A detailed study' Managing Development - The Governance Dimension, 1994, Washington D.C.

[31]. Weiss, T.G. (2000) "Governance, Good Governance and Global Governance: Conceptual and actual Challenges" in Third World Quarterly, Vol.21.No.5

[32]. Yaqub, N. \&Mikailu, A.S. (2003) "Accountability and Good Governance as Essential elements of Democratic Politics: An Analysis of their Institutionalization in Contemporary Politics of Nigeria" in Kwanashie, M. (Ed) Politics and Power Relations in Nigeria, Lagos, Dat and Partners Logistics Ltd. 